\title{
The changing nature of the international business field, and the progress of JIBS
}

\author{
John Cantwell ${ }^{1}$ and \\ Mary Yoko Brannen ${ }^{2}$ \\ ${ }^{1}$ Rutgers University, 1 Washington Park, Newark, \\ NJ 07102, USA; ${ }^{2}$ Gustavon School of Business, \\ University of Victoria, PO Box 1700, STN CSC, \\ Victoria, BC V8W 2Y2, Canada \\ Correspondence: \\ J Cantwell, Rutgers University, 1 Washington \\ Park, Newark, NJ 07102, USA. \\ e-mail: cantwell@business.rutgers.edu
}

\begin{abstract}
The Journal of International Business Studies (IIBS) is a journal with a high academic standing, and the leading journal in the field of international business (IB) research. It has become more open to new authors and to a wider range of IB scholarship. IB scholars study cross-border aspects of business activity. Some recent JIBS special issues have facilitated certain innovative new streams of IB research. Both the authors and the reviewers of the journal have become substantially more geographically diverse recently. Journal of International Business Studies (2016) 47, I023-103I. doi: 10.1057/s4 | 267-016-0041-0
\end{abstract}

Keywords: JIBS; international business research; journal editors

\section{THE REPUTATION AND OPENNESS OF JBS}

As the Editor-in-Chief and Deputy Editor of JIBS for the past 6 years, the time has come for us to briefly reflect on the progress of the journal over that period, and on the changing nature of the international business (IB) research field more widely. When we took up our new roles with JIBS in 2010-2011 there was still a great deal of discussion among AIB members and in many schools about whether JIBS warranted the status of an ' $A$ ' journal. This was a matter of serious concern in our community, since unless high quality IB research is properly recognized and rewarded in the tenure and promotion processes of schools, our field of scholarship is undermined, and younger researchers may either be unfairly penalized or simply retreat from IB research altogether. Moreover, without the counterbalance of strong IB scholarship as published in JIBS, unsophisticated IB research as sometimes published in disciplinary journals would go unchecked. Although there will always periodically be some schools and some departments in which the standing of JIBS is challenged (usually because they have no tradition or knowledge of IB research, or occasionally due to the outcome of intra-school politics over restrictive journal lists), we believe that for the most part JIBS is now widely recognized as an ' $\mathrm{A}$ ' journal by business school scholars who are not IB specialists. This is an immense and important achievement, because it hangs in part on the painstaking development of a scholarly identity and reputation that goes beyond any set of quantitative indicators (or for that matter, any particular editor or editorial team). Journal impact factors fluctuate from one year to another (especially the 
sensitive two year impact factor), but underlying reputations in academia exhibit greater inertia, and tend not to be so easily moved - although they can doubtless be lost more readily than they can be won.

Therefore, we were extremely pleased when in the Association of Business Schools (ABS) Academic Journal Guide for 2015, JIBS was ranked as a $4^{*}$ world elite journal, which represents the highest possible journal classification. The world elite club is often referred to as a list of 'A+' journals for all the business fields, those publications that stand at the pinnacle even of ' $A$ ' journals. The ABS Guide is widely used, especially in Europe, to determine the rankings of journals in school promotion and tenure processes. In this guide JIBS has now joined a distinctive club which consists of the top 33 journals out of a total 1,401, which puts us in the top $2.4 \%$ of all academic journals in the business and management fields as a whole, and JIBS is the only IB journal so distinguished. As a general indication of where this evaluation of journal quality places JIBS, we are ranked in the same highest category as journals such as e.g. the Academy of Management Journal (in Management), the American Economic Review (in Economics), the Journal of Finance (in Finance), the Journal of Marketing (in Marketing), or the Annual Review of Sociology (in the Social Sciences). This world elite distinction among ' $A$ ' journals is based in part on how widely a journal is recognized in various other published journal rankings lists, and so our elevation into this group has been grounded precisely on the strength and breadth of our scholarly reputation among business school researchers from a variety of disciplines.

In turn such external acknowledgement of the high standing of JIBS has the added effect of an increase in submissions, and last year we recorded by a comfortable margin the highest level of annual submissions to the journal. In 2015 we received 911 submissions, whereas for the earlier years in our term we had seen between 709 and to 760 submissions per year, which had in other words been quite a consistent number. Yet what pleases us more than the absolute number of submissions is the increasing breadth of JIBS articles, in two respects, both of which closely reflected our original objectives for our editorial term (Cantwell \& Brannen, 2011). First, the range of disciplines represented in JIBS has been steadily rising, and interdisciplinary contributions have gradually become more noticeable and important to the content of the journal. As we documented in an earlier editorial (Cantwell, Piepenbrink, \& Shukla, 2014), using an analysis of cross-journal citation patterns, JIBS has begun to play a role in helping to bridge disciplines that do not otherwise talk to each other, which is of critical importance to creating pervasive types of new knowledge that inform multiple domains of business scholarship. In this analysis we showed how JIBS has been enabling the integration of knowledge from a diverse set of disciplines, to a greater extent than most other prominent leading management journals.

In terms of our growing outreach and the impact of JIBS across related disciplines, the journals in which JIBS articles have been cited recently include the Journal of Financial Economics, the Journal of Finance, the Journal of Banking and Finance, the Accounting Review, Accounting, Organizations and Society, the Journal of Applied Psychology, Environmental Science \& Technology, Research Policy, the Journal of Economic Geography, and the Journal of Economic Perspectives, among others. This is in addition to the citation of JIBS research at a higher rate of frequency than in the past in some mainstream management journals, such as the Strategic Management Journal, the Academy of Management Journal, the Academy of Management Review, and the Journal of Management.

Second, as we discussed in another recent editorial (Cantwell, Piepenbrink, Shukla, \& Vo, 2016), JIBS has become more open and accessible to new authors, and more open to authors from a much wider range of locations of origin and of current residence. While the proportion of first-time contributors to JIBS has been sustained at a high level (despite the ever rising 'stock' of past JIBS authors that may still submit to the journal), during our editorial term for the first time we have witnessed a decline in the share of authors with multiple (three or more) past JIBS publications. We have also seen a steady increase in the proportion of JIBS authors originating from Europe and Asia, and from China in particular. Of course, part of the explanation for this broader geographic scope of authors has been the trend towards an increase in international research collaboration, which is far from unique to the IB field. Thus, in the science and engineering disciplines the share of academic journal articles that are internationally coauthored has risen from $8 \%$ in 1988 to $25 \%$ in 2012 . Yet this pales by comparison with the equivalent growth in the proportion of JIBS articles that are internationally coauthored: from $16.7 \%$ in 1988 to $66.7 \%$ in 2012 . This development of scholarship in the IB field is 
partly attributable to significant migration in our community, which has doubtless helped to facilitate cross-border collaborative research. We have found that just over $50 \%$ of JIBS authors are employed outside their country of birth, and a further $12 \%$ of our authors are returnees to their country of origin, having spent a significant part of their professional lives abroad. This underscores an observation we had made in our opening editorial (Cantwell \& Brannen, 2011), that within our community we have a high proportion of scholars who have experience both of career interests in different disciplines, and at the same time a knowledge of professional life in different countries, who therefore have a much keener appreciation of the relevance of diverse contexts for understanding and theorizing about phenomena. We are delighted to see that this valuable asset for IB research is now being more fully realized and expressed through JIBS.

\section{THE CONTENT OF THE JOURNAL}

We believe that to become recognized as being amongst the best journals, but also now to retain our position in that respect, it is essential that JIBS has a clear identity that differentiates it from other leading journals. We have been pleased to see that during our term the definition of IB (and the fact that JIBS is an IB journal) has become clearer to the broad range of scholars who submit their work to the journal. That is, for inclusion in JIBS, the business activity being studied must have some cross-border element to it, and the analysis of that cross-border component needs to be the focus of attention of the study. While we do still receive a significant number of submissions that are outside our remit as an IB journal (e.g., which study some aspect of business activity in an apparently exotic location, in which what is 'international' is merely subjective, since it depends on the location of the scholar), the share of these submissions has gradually fallen during our editorial term, despite the broadening range of our author base. Perhaps we have been helped in this endeavor not merely by our own insistence on following our statement of editorial policy, but also by the steady continuation in the trend towards the globalization of business activities, which has created an ever expanding scholarly interest in our IB subject.

Moreover, we believe the fact that JIBS has now been recognized as a leading business and management journal is testament to IB's maturity as a field and to the development of a clear identity of what constitutes IB research. Historically, IB has lacked a common identifying focus, beyond the desire to understand the nature of the empirical phenomenon of the multinational enterprise (MNE) and its activities. For too long, IB research has remained divided into two separate camps, each with their own distinct perspective. The first of these has stemmed from economics and has offered a 'bird's eye', macro view of IB, that has provided the larger contextual basis for advancing IB theories on public policy, MNE strategy, and so forth. The other track has stemmed from cross-cultural management frameworks that have focused on individual level analyses, which have provided the theoretical underpinnings for international organization behavior and international human resource management. These perspectives were originally developed largely independently of one another. The economics/strategy perspective did not connect much with the cross-cultural comparative management perspective, and vice versa. This original lack of a common starting point left room for multiple unrelated entry points into IB research. Now, having a clear definition of what constitutes IB research, IB is able to distinguish itself as a mature field of increasingly interconnected scholarship that is able to mobilize knowledge inputs or ideas from disparate disciplines to shed light on a more focused research agenda.

As a further aspect of our identity as an IB journal, we have asked that each article that we publish make some contribution to our theories and conceptualization of IB. In this sense, we do not look only for the study of an IB (cross-border business) activity as an empirical phenomenon, but we expect each published article to explain how this relates to our wider analytical understanding of $\mathrm{IB}$, and hence why the article is potentially of interest to any IB scholar, and not just to those specialized on the immediate topic under examination. For our editorial team this goal has become more important as the breadth of articles that we have accepted has risen; we have been publishing across a wider range of disciplines, including more interdisciplinary forms of research, and a significantly higher proportion of qualitative papers. In order to ensure that the journal retains its coherence, and beyond this that scholars from different disciplines and from different methodological backgrounds continue to interact with one another in substantive and meaningful ways within the IB field, it is vital that we also have some common 
language and conceptual frameworks. One of us has argued that the eclectic paradigm is one such framework that has proved readily adaptable for this purpose (Cantwell, 2015). Yet whichever IB framing of their analysis is deemed to be most suitable by the authors of an article, such IB positioning of the article is what makes it distinctively belong to JIBS. The same study and the same set of findings, had they instead appeared in a discipline-specific journal (such as the Academy of Management Journal for management, or the Journal of Finance, for finance), might well have been couched differently, and in terms that would tend to render that paper more exclusively to scholars within the relevant discipline. Of course, this has also been part of our objective of broadening our IB conversations to include a wider scholarly community, and to break any perception that it is difficult for 'outsiders' to access JIBS, as we discussed earlier.

One of the ways in which we have brought new streams of IB scholarship to JIBS is through special issues that connect our already established AIBbased community with a grouping of scholars that have operated mainly outside the AIB, often in some cognate discipline. Our objective has been to boost the number of good submissions attracted to JIBS, especially where we have identified a clear community of scholarship in the area in question which is germane to IB but not yet much integrated with mainstream IB studies. However, we have also been clear that a special issue proposal and the associated call should not read as if it is itself a research project proposal or the pursuit of a fairly narrow research agenda associated with some particular perspective or a given group of scholars, but rather it should be written in a way that is open to a wide variety of potential approaches and to different ways of thinking about the subject. This is essential if a call for papers is to attract the level of submissions that would eventually lead to the production of a diverse and interesting special issue. In our view it is no accident that as a result of our selection criteria all our calls have led to successful special issues, of which we have had seven to date (see Table 1). With the same aim in mind, we have also run a competitive process to attract the best special issue ideas, and in many cases we have organized author workshops in order to encourage the development of individual papers and research streams in ways that are more likely to be impactful.

We have also taken care to involve a member of our regular editorial team in each of the guest editor groupings, in order to ensure a commonality of editorial policy and objectives, but also to provide the opportunity for our specialist area editors to bring more people they know from their wider scholarly networks into the JIBS author and reviewer pool. Again, we think that this has worked extremely well. We have initiated 12 calls for papers for special issues, of which seven have already been published (Table 1), and a further five are currently in progress (see Table 2). No less than eleven different members of our regular editorial team have contributed to these special issue guest editor teams. The published special issues have helped to establish or to re-establish the linkages between IB scholarship and research in areas as far apart as economic geography, regional science, language studies and linguistics, political science, cultural studies, and engineering and management. We are particularly pleased that most of our special issues have not been isolated forays, but they have been followed by further JIBS articles in the same area of research. This has probably been both because we have managed to identify emergent research areas for special issues ahead of the curve, and because the special issue process itself has signaled our interest and so attracted new submissions to the journal that might not otherwise have come our way. In order to draw attention both to some of these newer IB research themes, as well as the relevance of some of our longer established IB research streams for scholars developing an interest in our field, we have begun a series of JIBS virtual collections (see Table 3). Each of these has then fed into a contribution to the new JIBS book series, published by Palgrave Macmillan.

We have been conscious as well of our responsibility as an editorial team not just to attract more submissions to the journal in the here and now, but also to invest in the future of our IB research field. This requires us to help encourage younger scholars interested in taking up IB research, and to help support the emergence and building of IB scholarly communities in countries and areas in which the AIB has recruited its first members recently, or has seen a significant recent growth in membership. In terms of the articles that have now begun to reach the journal, we have seen the benefits not just of our own annual JIBS paper development workshop (PDW) at the AIB conference that we have run each year, but also the fruits from our participation (with the encouragement and support of the AIB Board) in a series of AIB chapter JIBS workshops at locations around the world (see Table 4). In addition, we 
Table 1 JIBS special issues, 2013-2016

The Multinational in Geographic Space

Editors: Ulf Andersson, Sjoerd Beugelsdijk, Ram Mudambi, and Srilata Zaheer

Vol. 44, No. 5, 2013

The Multifaceted Role of Language in International Business: Unpacking the Forms, Functions and Features of a Critical Challenge to MNC Theory and Performance

Editors: Mary Yoko Brannen, Rebecca Piekkari, and Susanne Tietze

Vol. 45, No. 5, 2014

Advancing Interdisciplinary Research in International Business: Integrative Knowledge and Transformative Theories

Editors: Joseph L. C. Cheng, Julian Birkinshaw, Donald Lessard, and David C. Thomas

Vol. 45, No. 6, 2014

Governments as Owners: Globalizing State Owned Enterprises

Editors: Kannan Ramaswamy, Andrew Inkpen, Aldo Mussachio, and Alvaro Cuervo-Cazurra

Vol. 45, No. 8, 2014

What Is Culture and How Do We Measure It?

Editors: Timothy M. Devinney, Bradley L. Kirkman, Dan V. Caprar, and Paula Caligiuri

Vol. 46, No. 9, 2015

Internationalization in the Information Age

Editors: Juan Alcacer, John Cantwell, Giovanni Dosi, Sergio Mariotti, and Lucia Piscitello

Vol. 47, No. 5, 2016

Widening the Lens: Rethinking Distance, Diversity, and Foreignness in International Business Research Through Positive Organizational Scholarship

Editors: Günter K. Stahl, Rosalie L. Tung, Tatiana Kostova and Mary Zellmer-Bruhn

Vol. 47, No. 6, 2016

Table 2 JIBS special issues, forthcoming or in progress

International Business Responses to Institutional Voids

Editors: Jonathan Doh, Suzana Rodrigues, Ayse Saka-Helmhout, Mona Makhija

The Role of Financial and Legal Institutions in International Corporate Governance

Editors: Douglas Cumming, Igor Filatotchev, April Knill, Lemma Senbet, David Reeb

Zoom In, Zoom Out, and Beyond: Locational Boundaries in International Business

Editors: Ron Boschma, Shige Makino, Gongming Qian, Xufei Ma, Lee Li, Ram Mudambi

The Creation and Capture of Entrepreneurial Opportunities Across National Borders

Editors: Gary Knight, Peter Liesch, Lianxi Zhou, Rebecca Reuber

Making Connections: Social Networks in International Business

Editors: Ilya Cuypers, Gokhan Ertug, Martin Kilduff, Akbar (Aks) Zaheer, John Cantwell

have contributed various presentations and promotional efforts at suitable conferences or at the invitation of members of other organizations (as shown in Table 5).

With respect to the role of JIBS in the continued development of the IB field, we have seen a slow but steady increase in what might be called 'big picture' articles, in which important new ideas have been articulated. The emphasis in our editorial policy on the 'three I's', namely that our goal for JIBS is to publish insightful, innovative and impactful IB research, appears to have helped authors as to what we as editors have been looking for. This has helped us to somewhat revitalize the Perspectives category of articles, of which we have published a number. Ten conceptually 
Table 3 JIBS virtual collections, leading to contributions to the new JIBS book series

Location, edited by John Cantwell (2014)

The eclectic paradigm, edited by John Cantwell (2014)

Language, edited by Mary Yoko Brannen (2015)

State-owned multinationals, edited by Alvaro Cuervo-Cazurra (2016)

International entrepreneurship, edited by Rebecca Reuber (2016)

Table 4 JIBS presentations and promotions at AIB chapters or affiliates

AIB Middle East - North Africa (MENA) chapter, December 2010, January 2012, January 2013, and August 2016

AIB UK and Ireland chapter, March 2012, and April 2015

AIB South East Asia chapter, December 2012, and December 2013

AIB India chapter, April 2013, and December 2014

AIB Latin America chapter, April 2013, March 2014, and January 2015

AIB Japan chapter, May 2013

AIB South East US chapter, October 2013

AIB North East US chapter, October 2013, November 2014, and November 2015

AIB Western European chapter, December 2013, December 2014, and December 2015

BALAS conference, April 2014

ANZIBA conference, February 2015

developmental Perspectives articles that have appeared in JIBS during our 2011-2016 editorial term are listed in Table 6. Although we have also had a policy of not publishing pure review articles (which may well be impactful, but tend to be less insightful or innovative), a good Perspectives paper does much more than just review the relevant literature. What a paper does beyond its literature review is different in the case of each submission category. We expect a Perspectives article to synthesize the literature in some novel way, and to critically evaluate it so as to offer a new perspective on it (hence the label) and suggest new research direction(s). A Perspectives paper must make and clearly identify its contribution to our theory and conceptualization of IB, just like any other JIBS article, and it is reviewed to the same standards as any other article.
Since we have encountered questions which seem to suppose otherwise, it is worth noting that we have taken the view that Perspectives submissions are not specially invited by the Editor-in-Chief of the journal, any more than are submissions in the other categories. Appropriate submissions are always welcome in JIBS, from whomever they come and in whichever of the recognized submission categories they fall, and we have no inside track. Of course, we are well aware that other IB journals have successfully invited articles that were subsequently well cited, and indeed that JIBS has done so in the past. This strategy seems entirely appropriate for a newer journal, especially in its start-up phase. Instead, JIBS has now reached a mature stage in its development as a journal, and perhaps so too has the IB field more generally. This changed context has required shifting from inviting contributions 
Table 5 JIBS presentations and promotions at other organizations

Florida International University, April 2010, and October 2012

Purdue University, April 2010

American Marketing Association, February 2011, and February 2013

Erasmus University, Rotterdam, March 2011

CIBERs Ph.D. Conference, July 2011

Taylor and Francis (Routledge) journal editors' roundtable, October 2011

Strategic Management Society, November 2011

Fordham University, February 2012

EIBA Annual Conference, December 2012, and December 2015

École Polytechnique, October 2013

Duke CIBER Ph.D. workshop, July 2014

Academy of Management annual conference, August 2011-2015

University of Sussex, October 2014

University of Bath, November 2014

Family Enterprise Research Conference, June 2015

Virginia Tech, April 2016

from selected leading figures in some target areas of IB scholarship as a catalyst to attracting other submissions, to now ensuring a level playing field for all authors in what is the leading publication outlet for the field. Whenever they are accepted, Perspectives articles can appear throughout the year in any issue of the journal - the occasional special issues we run are organized by specific topics or themes, not by article category. Thus, for example, in the recent special issue on International Business in the Information Age we included a Perspectives piece and a Research Note, in addition to the regular Original Manuscript contributions.

\section{THE JIBS EDITORS AND EDITORIAL REVIEW BOARD}

The achievements of our editorial term have depended heavily on the scholarly excellence and the tremendous efforts of our full editorial team. With the objectives we have outlined in mind, the members of our team were recruited to ensure that we had a diversity of expertise, a diversity of disciplinary backgrounds and interests, and a geographic diversity of current institutional affiliations, spanning North America, Europe and Asia. A similar pattern was gradually reflected in the composition of our editorial review board, as we elected new boards around every 18 months, to take account of the most recent records of our board members as reviewers (both in terms of the number of reviews they accepted, and in our evaluation of the quality of those reviews). Comparing the first editorial review board we elected in 2010 with the last one we elected in 2015, the number of members from North America fell by six - but while Canadian representation rose by five, the US-based participation fell by eleven. European membership rose by 15 , with an increase of seven from Denmark (due to the increased status of the Copenhagen Business School at this time), a rise of four from Italy, and an increase of three from Austria. 
Table 6 JIBS perspectives category articles, 2011-2016

Doz, Y. 2011. Qualitative research for international business. Journal of International Business Studies, 42(5): 582-590 Burgelman, R. A. 2011. Bridging history and reductionism: A key role for longitudinal qualitative research. Journal of International Business Studies, 42(5): 591-601

Westney, D. E., \& Van Maanen, J. 2011. The casual ethnography of the executive suite. Journal of International Business Studies, 42(5): 602-607

Teece, D. J. 2014. A dynamic capabilities-based entrepreneurial theory of the multinational enterprise. Journal of International Business Studies, 45(1): 8-37

Buckley, P. J. 2014. Adam Smith's theory of knowledge and international business theory and practice. Journal of International Business Studies, 45(1): 102-109

Hoenen, A. K., \& Kostova, T. 2015. Utilizing the broader agency perspective for studying headquarters-subsidiary relations in multinational companies. Journal of International Business Studies, 46(1): 104-113

Stahl, G. K., \& Tung, R. L. 2015. Towards a more balanced treatment of culture in international business studies: The need for positive cross-cultural scholarship. Journal of International Business Studies, 46(4): 391-414

Gligor, D. M., Esmark, C. L., \& Gölgeci, I. 2016. Building international business theory: A grounded theory approach. Journal of International Business Studies, 47(1): 93-111

Brouthers, L. E., Marshall, V. B., \& Keig, D. L. 2016. Solving the single-country sample problem in cultural distance studies. Journal of International Business Studies, 47(4): 471-479

Laplume, A. O., Petersen, B., Pearce, J. M. 2016. Global value chains from a 3D printing perspective. Journal of International Business Studies, 47(5): 595-609

Membership also rose slightly from Finland, France, Spain, Switzerland and the UK, and fell slightly from Germany, Sweden and Turkey. The highest proportional increase came from Asia, from 10 members to 16 , of which higher numbers of members were located in China, Hong Kong, Japan, Singapore and Korea. Editorial board membership from Australasia and from the Middle East remained about the same.

As well as looking for a well balanced mix of geographical backgrounds, subject knowledge, skills and interests among our editors, we took care to make sure that all our editors have been as comfortable in handling qualitative empirical studies as they have been in assuming responsibility for quantitative manuscripts. We decided against having a specialist qualitative methods editor, or for that matter any editor specifically assigned for some particular branch of methodology. JIBS is not and has never been a methods journal, and since our area editors have each covered some broad sub-field of IB research, we needed to be confident that within each such sub-field, scholarship would be assessed according to equivalent standards whatever the appropriate methodology might be to address a given research question. This also meant that we made efforts as well to remove any potential bias in the methodological expectations of our editorial review board (in the early days we did occasionally have reviewers who appeared wrongly to presume that in empirical research, JIBS was a purely quantitative journal). We have also broadened the methodological expertise of our editorial review board to include more members who can effectively evaluate qualitative papers.

Our editorial team has intentionally functioned cohesively, and more so over time, as we have met and interacted regularly, which has helped to ensure the development and rapid dissemination of best practice. When questioned, many academic researchers will say that of all they have done, they are most proud of their former doctoral students, and of their achievements. In a similar vein, what has pleased us the most, and made us proud, has been working with our editorial team, and seeing them develop in the role, and in their associated stature in the profession. It has been gratifying that four of our JIBS editorial team were individually elected as AIB Fellows this year, in the final year of our term. This is the best and the most appropriate recognition that we could receive, through the collective professional success of our colleagues. 
By creating shared norms and values among our editors through meeting together and through conversations around issues as they arose, and by agreeing upon and implementing shared working practices (with the support of our ever-efficient and tireless JIBS Managing Editor Anne Hoekman!), we have been able to function interdependently as an editorial team, despite each having our own individual responsibilities. This strong editorial team ethic and the cultivation of a very high degree of mutual trust and respect has been extremely important in ensuring the maintenance of common standards and procedures across all the various sub-fields of IB research. It has also allowed our editors to take individual initiatives in their areas, not least through the special issues we have mentioned already. In addition, the members of our editorial team have worked together on editorials for the journal, which we believe have been part of a professional developmental process by which we have helped both our authors and our reviewers.

We began our first editorial in 2011 by thanking and acknowledging the tremendous contributions to JIBS that had been made by our immediate predecessors as Editors-in-Chief, Lorraine Eden and Arie Lewin. It is most fitting for us to close this final editorial by wishing every success to our successor as JIBS Editor-in-Chief Alain Verbeke and his incoming editorial team. As we have tried to explain in the foregoing, while each new editor of

\section{REFERENCES}

Cantwell, J. A. 2015. An introduction to the eclectic paradigm as a meta-framework for the cross-disciplinary analysis of international business. In The eclectic paradigm: a framework for synthesizing and comparing theories of international business from different disciplines or perspectives. London, New York: Palgrave Macmillan, http://ssrn.com/abstract=2640705, accessed 4 April 2016.

Cantwell, J. A., \& Brannen, M. Y. 2011. Positioning JIBS as an interdisciplinary journal. Journal of International Business Studies, 42(1): 1-9.
JIBS builds upon the strengths of the journal they have inherited from the efforts of many past editors and contributors, they also bring some distinctive new characteristics and some specific goals of their own that help to shape the journal as it moves further forward during their term as editors. This is one reason why we support the general supposition over the years of AIB Boards (who appoint the JIBS Editor-in-Chief) that editors should normally serve no more than two terms (like US Presidents!). It is best for the journal that its leadership turns over periodically. It is very encouraging for JIBS that Alain is so keen and enthusiastic to take on this role, as we have seen from our conversations during the smooth and effective transition process between editors. Alain is a highly insightful IB scholar who holds himself to the highest professional and ethical standards in his own conduct, which bodes well for the future management of the journal. We look forward with great interest to the next chapter in the story of JIBS, in which Alain Verbeke will now take on the lead role.

\section{ACKNOWLEDGMENTS}

The authors would like to thank Saeed Rahman for helpful research assistance during the preparation of this editorial.

Cantwell, J. A., Piepenbrink, A., \& Shukla, P. 2014. Assessing the impact of JIBS as an interdisciplinary journal: A network approach. Journal of International Business Studies, 45(7): 787-799.

Cantwell, J. A., Piepenbrink, A., Shukla, P., \& Vo, A. 2016. The changing landscape of JIBS authorship. Journal of International Business Studies, 45(7): 749-777. 